\title{
Complete genome sequence of a previously undescribed monopartite begomovirus and betasatellite infecting Malvastrum coromandelianum in Cambodia
}

\section{Yafei Tang}

Guangdong Academy of Agricultural Sciences

Zhenggang Li

Guangdong Academy of Agricultural Sciences

Xiaoman She

Guangdong Academy of Agricultural Sciences

Lin $\mathrm{Yu}$

Guangdong Academy of Agricultural Sciences

Guobing Lan

Guangdong Academy of Agricultural Sciences

Lihua LV

Guangdong Academy of Agricultural Sciences

Judith K Brown

University of Arizona

Zi-fu He ( $\nabla$ hezf@gdppri.com )

Guangdong Academy of Agricultural Sciences https://orcid.org/0000-0002-0024-8378

\section{Research Article}

Keywords: Begomovirus, betasatellite, Malvastrum coromandelianum, Kampot province, Cambodia

Posted Date: March 4th, 2021

DOI: https://doi.org/10.21203/rs.3.rs-268352/v1

License: (c) (i) This work is licensed under a Creative Commons Attribution 4.0 International License. Read Full License

Version of Record: A version of this preprint was published at Archives of Virology on April 3rd, 2021. See the published version at https://doi.org/10.1007/s00705-021-05016-y. 


\section{Abstract}

A previously undescribed monopartite begomovirus was identified from Malvastrum coromandelianum plants exhibiting yellow vein symptoms characteristic of begomoviruses, in Kampot province, Cambodia. The apparently full-length viral component was cloned and sequenced following enrichment of circular DNA by rolling circle amplification and restriction enzyme digestion. The genome of the virus was 2,737 nucleotides in length (KP188831), and exhibited an organization like that of other monopartite begomoviruses, sharing the highest $n t$ identities of $87.7 \%$ with Ageratum yellow vein virus (AM940137). A satellite molecule was amplified from total DNA by PCR amplification with the betasatellite-specific primer pair $\beta 01 / \beta 02$. The satellite molecule $(1,346 \mathrm{nt}, \mathrm{KP} 188832)$ had a structure characteristic like other betasatellites associated with begomoviruses, and shared the highest nt identity of $84.8 \%$ with Malvastrum yellow vein betasatellite (MN205547). According to the criteria established for species demarcation for classification of begomoviruses (Geminiviridae) and betasatellites ( Tolecusatellitidae ), respectively, the virus isolate from $\mathrm{M}$. coromandelianum in Cambodia is a previously undescribed novel monopartite begomovirus species $₫$ for which the name Malvastrum yellow vein Cambodia virus (MaYVCV) is proposed, whereas, the betasatellite is identified as an previously undescribed novel betasatellite species, for which the name Malvastrum yellow vein Cambodia batesatellite (MaYVKHB) is proposed.

\section{Main Text}

Plant viruses of the family Geminiviridae have a circular, single-stranded DNA genome encapsidated in a twinned icosahedral particle. They are important global pathogens that cause serious yield losses in many crops. The family includes nine genera, namely Becurtovirus, Begomovirus, Capulavirus, Curtovirus, Eragrovirus, Grablovirus, Mastrevirus, Topocuvirus, and Turncurtovirus, based on genome organization, insect vector, and host range [1, 2]. The genus Begomovirus (family Geminiviridae) is the largest group within the family, comprising at least 424 species recognized by the International Committee on Taxonomy of Viruses (ICTV) (http://www.ictvonline.org/virusTaxonomy.asp), and economically, it is the most important, causing yield losses in many crops, including cassava, cotton, and tomato.

Begomoviruses are widely distributed in tropical and subtropical regions of the world and are transmitted exclusively by the whitefly Bemisia tabaci (Gennadius). They can have either a monopartite (DNA-A) or bipartite (DNA-A and DNA-B) genome configurations, depending on the number of genome components they possess [3]. The begomoviral DNA-A or DNA-B component is $\sim 2.6-2.8 \mathrm{~kb}$ in size, while the monopartite genome is about $2.8 \mathrm{~kb}$ in size. The DNA-A and monopartite genomes encode mostly functionally comparable viral proteins: $A \mathrm{~V} 1$ and $A V 2$ on the virion-sense strand and $A C 1, A C 2, A C 3$ and AC4 on the complementary strand, for replication, control of gene expression and encapsidation. DNA-B encodes BV1 and BV2 for movement of the virus in plant cells [4]. Many satellite DNA molecules of approximately $1.3 \mathrm{~kb}$ in size have been discovered associated with begomoviruses. These satellite DNA molecules are classified as either betasatellites (genus Betasatellite, family Tolecusatellitidae), or alphasatellites (family Alphasatellitidae). Some satellite DNA molecules of approximately $0.7 \mathrm{~kb}$ in size 
have been discovered associated with begomoviruses and classified as deltasatellites (genus Deltasatellite, family Tolecusatellitidae) $[5,6]$. Betasatellites are involved in the development of disease symptoms, a characteristic that is attributed to their function as a suppressor of host plant gene silencing. Begomovirus-betasatellite complexes cause important diseases of vegetables, fiber crops, and ornamental plants and infect many uncultivated wild plant species [7].

The perennial plant species Malvastrum coromandelianum is native to South America but has been introduced and established in tropical and subtropical regions, including Asia. To date, at least 10 begomoviruses have been found first in $M$. coromandelianum plants [8-15].

In October 2014, three leaf samples, Ca-1, Ca-2 and Ca-3, were collected from three different $M$. coromandelianum plants exhibiting yellow vein symptoms in Kampot Province, Cambodia (Fig. 1). Total DNA was extracted using an EasyPure Plant DNA Kit (TransGen Biotech, Beijing, China). To detect the suspected begomovirus, PCR amplification was carried out using degenerate primers to amplify the coat protein gene $(c p)\left(\mathrm{AV}_{494} / \mathrm{CoPR}\right)[16,17]$ with an expected amplicon size of $\sim 570 \mathrm{bp}$. An amplicon of the expected size was obtained from all three samples. Sequencing of the amplicon from each sample confirmed the presence of a begomovirus in the symptomatic $M$. coromandelianum plants based on the closest matches of the sequences in a BLASTn search of the GenBank database with ageratum yellow vein virus [AM940137], with 95.61\% nt sequence identity and $100 \%$ coverage.

The complete genome of the putative begomovirus was amplified from one sample by rolling-circle amplification (RCA) (TempliPhi kit; GE Healthcare, Buckinghamshire, UK), followed by digestion with BamHI and HindIII endonucleases (Fermentas, GlenBurnie, MD, USA). The digestion of RCA products with the BamHI restriction enzyme yielded a 2.7-kbp DNA fragment. The fragments $(n=3)$ were gel-purified and ligated into the plasmid vector pGEM-3Z (Promega Co., Madison, WI, USA), which had been digested with BamHI, introduced into Escherichia coli DH5a by transformation, and sequenced (Invitrogen Co., Shanghai, China). Total DNA was used as template for PCR amplification with primers for DNA-B components, betasatellites, and alphasatellites (PBLIv2040/PCRc1 [18], $\beta 01 / \beta 02$ [19], and DNA101/DNA102 [20], respectively).

The amplicons were gel-purified and ligated into the plasmid vector pMD19-T (Takara Biomedical Technology Co., Beijing, China). All plasmids were introduced into Escherichia coli DH5a and sequenced (Invitrogen Co., Shanghai, China). The DNA sequences were assembled, edited, and analyzed using DNAStar software version 5.0 (DNASTAR Inc., Madison, WI, USA). Preliminary identification of the begomovirus was done by comparing its sequence to sequences available in the GenBank database using BLASTn (www.ncbi.nlm.nih.gov) [21]. The pairwise nucleotide (nt) sequence identity was determined using a MUSCLE alignment and the Sequence Demarcation Tool (SDT 1.2) [22].

The insert sequences of three clones, Ca-1, Ca-2 and Ca-3 (2,737 nt), from RCA products digested with BamHI were $99.6 \%-100 \%$ identical to one another. The sequence of Ca-1 was chosen as the representative genome sequence of this begomovirus and deposited in the GenBank database under the 
accession number KP188831. The sequence had the typical genome organization of a monopartite Old World begomovirus, containing six predicted open reading frames (ORFs).

Based on SDT analysis, the pairwise nt sequence identity values ranged from 69.9 to $87.7 \%$ in comparisons of the viral component from this study to those of 21 other closely related begomoviruses available in the GenBank database. The viral component shared the highest nt sequence similarity $(87.7 \%$ identity) with ageratum yellow vein virus (AYVV, AM940137) and Malvastrum leaf curl Philippines virus (MaLCPHV, KC577540) (87.5\% identity). Based on the species demarcation threshold for begomoviruses (91\% nt sequence identity) [15], this virus isolated from M. coromandelianum in Cambodia is a previously undescribed begomovirus, for which the name "malvastrum yellow vein Cambodia virus" (MaYVCV) is proposed.

Phylogenetic analysis carried out using MEGA [23] (maximum likelihood with bootstrap values $>50 \%$ and 1000 iterations) between MaYVCV and 21 other begomoviral DNA-A sequences showed that it clustered with AYVV (AM940137), stachytarpheta leaf curl virus (StaLCuV, AJ564743), MaLCPHV (KC577540), and tomato leaf curl Mindanao virus (ToLCMiV, EU487046) to form a unique clade (Fig. 2A).

Recombination analysis was carried out with default settings in Recombination Detection Program (RDP) 4.0, using the GENECOV, Max Chi, RDP, Bootscan, Chimaera, 3Seq, and SiSan algorithms [24], but no recombination events were detected in MaYVCV.

The M. coromandelianum samples were tested by PCR for the presence of DNA-B, betasatellites, and alphasatellites, using the primer pairs PBLIv2040/PCRc1 [18], $\beta 01 / \beta 02$ [19], and DNA101/DNA102 [20], respectively. An amplicon of $\sim 1.4 \mathrm{~kb}$ was obtained for samples from three diseased plants using $\beta 01 /$ $\beta 02$, but no amplicon was obtained with PBLIv2040/PCRc1 or DNA101/DNA102, suggesting the presence of an associated betasatellite, but no alphasatellite or DNA-B component.

The betasatellite was 1,346 nt in length (GenBank accession no. KP188832) and had the typical structure of a betasatellite, with a single ORF ( $\beta C 1$ ) located on the complementary-sense strand, an A-rich region, and a satellite conserved region (SCR) containing a predicted stem-loop structure with the nonanucleotide sequence TAATATTAC [7]. Based on SDT analysis, the pairwise nucleotide sequence identity between the betasatellite and betasatellites available in GenBank was $59.1-84.8 \%$. It shared the highest nt sequence similarity (84.8\% identity) with malvastrum yellow vein betasatellite from China (MaYVB, MN205547). Phylogenetic analysis indicated that it clustered with MaYVB (MN205547) to form a unique clade (Fig. 2B). Thus, according to the species demarcation threshold for betasatellites (91\% nt sequence identity) [25], this is a previously undescribed betasatellite, for which the name "malvastrum yellow vein Cambodia betasatellite" (MaYVKHB) is proposed.

Alphasatellites infecting malvaceous species have been reported throughout Asia, and also in Burkina Faso, Cameroon, Egypt, Kenya, and Mali [26], and deltasatellites infecting M. coromandelianum plants have been reported in Cuba [5]. However, these DNA satellites were not found in the analyzed samples. 
Wild plant hosts of viruses are known to be important reservoirs of begomoviruses and are expected to contribute to viral evolution and to the spread of viruses in cultivated crops. The identification and molecular characterization of viral genomes in wild plants and weeds contributes to our understanding of the genetic diversity, ecology, and evolution of begomoviruses. For example, malvastrum leaf curl virus has been identified infecting $M$. coromandelianum and was also detected in the cultivated fruit crop plant papaya [27], suggesting the wild host may serve as an important reservoir for the virus. Additional research is required to determine the extent of MaYVCV spread between M. coromandelianum and papaya and other cultivated plant species in Cambodia.

\section{Declarations}

\section{Compliance with ethical standards}

Acknowledgments This study was funded by the Scientific and Technological Assistance Project for Developing Countries, China (KY201402015), the National Natural Science Foundation of China (31871937), Guangdong Basic and Applied Basic Research Foundation (2019A1515012150), the Science and Technology Program of Guangzhou, China (201904010173), and the Special Fund for Scientific Innovation Strategy-Construction of High-Level Academy of Agriculture Science (R2019PY-JX005).

Conflict of interest The authors declare that they have no conflict of interest.

Ethical approval This research did not use human participants or other animals.

\section{References}

1. Varsani A, Navas-Castillo, Jesús, Moriones E, Hernandezzepeda C, Idris A M, Brown J K, Zerbini F M, Martin, D P (2014) Establishment of three new genera in the family geminiviridae: becurtovirus, eragrovirus and turncurtovirus. Arch Virol 159(8):2193-2203.

2. Varsani A, Roumagnac $P$, Fuchs $M$, Navascastillo J, Moriones E, Idris A M, Briddon R W, RivereBustamante R, Zerbini F M, Martin, D P (2017) Capulavirus and Grablovirus: two new genera in the family Geminiviridae. Arch Virol 162(6):1819-1831.

3. Navas-Castillo J, Fiallo-Olivé E, Sánchez-Campos S (2011) Emerging virus diseases transmitted by whiteflies. Annu Rev Phytopathol 49:219-248.

4. Hanley-Bowdoin L, Settlage S B, Orozco B M, Nagar S, Robert D (1999) Geminiviruses: models for plant DNA replication, transcription, and cell cycle regulation. Crit Rev Plant Sci 18: 71-106.

5. Fiallo-Olivé E, Martínez-Zubiaur Y, Moriones E, Navas-Castillo, J (2012) A novel class of DNA satellites associated with New World begomoviruses. Virology 426: 1-6.

6. Lozano G, Trenado HP, Fiallo-Olivé E, Chirinos D, Geraud-Pouey F, Briddon RW, Navas-Castillo J (2016) Characterization of non-coding DNA satellites associated with sweepoviruses (genus Begomovirus, Geminiviridae) - definition of a distinct class of begomovirus-associated satellites. Front Microbiol 7:162. 
7. Zhou XP (2013) Advances in understanding begomovirus satellites. Annu Rev Phytopathol 51:357381.

8. Alabi O J, Villegas C, Gregg L, Murray K D (2016) Complete nucleotide sequences of a new bipartite begomovirus from malvastrum sp. plants with bright yellow mosaic symptoms in south Texas. Arch Virol 161(6):1729-1733.

9. André P G, Martin D P, Roye M E (2010) Molecular characterization and phylogeny of two begomoviruses infecting Malvastrum americanumin Jamaica: evidence of the contribution of interspecies recombination to the evolution of malvaceous weed-associated begomoviruses from the northern Caribbean. Virus Genes 40(2):256-266.

10. Zhou X, Xie Y, Peng Y, Zhang Z (2003) Malvastrum yellow vein virus, a new begomovirus species associated with satellite DNA molecule. Chinese Sci Bull 48(20):2206-2210.

11. Jiang T, Liu P, Liao B L, Wu J X, Huang C J (2010) Malvastrum yellow vein yunnan virus is a monopartite begomovirus. Acta Virol 54(1):21-26.

12. Huang J F, Zhou X P (2006) Molecular characterization of two distinct begomoviruses from Ageratum conyzoides and Malvastrum coromandelianum in China. J Phytopathol 154(11-12):648653.

13. Rahman S U, Zubair M, Ahmed N, Khan M Z, Raza G, Amin I, Mansoor S (2019). Identification of "Malvastrum yellow vein Lahore virus" a proposed new species of begomovirus in association with cotton leaf curl Multan betasatellite infecting green bean (Phaseolus vulgaris) in Pakistan. Australasian Plant Disease Notes, 14(1), 1-3.

14. Guo X, Shi M, Zhou X (2007) Complete nucleotide sequences of Malvastrum yellow mosaic virus and its associated DNA $\beta$ molecule. Arch Virol 152(3): 641-643.

15. Brown J K, Zerbini F M, Navas-Castillo J, Moriones E, Ramos-Sobrinho R, Silva J C, Fiallo-Olive'E, Briddon R W, Herna'ndez-Zepeda C, Idris A, Malathi V G, Martin D P, Rivera-Bustamante R, Ueda S, Varsani A (2015) Revision of Begomovirus taxonomy based on pairwise sequence comparisons. Arch Virol 160:1593-1619.

16. Wyatt S D, Brown J K (1996) Detection of subgroup III geminivirus isolates in leaf extracts by degenerate primers and polymerase chain reaction. Phytopathology 86:1288-1293.

17. He Z F, Yu H, Luo F F (2004) Detection of whitefly-transmitted geminiviruses from tomato by PCR. Virol Sin 19:67-69.

18. Rojas M R, Gilbertson R L, Russell D R, Maxwell D P (1993) Use of degenerate primers in the polymerase chain reaction to detect whitefly-transmitted geminiviruses. Plant Dis 77, 340-347.

19. Briddon R W, Bull S E, Mansoor S, Amin I, Markham P G (2002). Universal primers for the PCRmediated amplification of DNA $\beta$. Mol Biotechnol 20:315-318.

20. Bull S E, Briddon R W, Markham P G (2003) Universal primers for the PCR-mediated amplification of DNA 1: a satellite-Like molecule associated with begomovirus-DNA beta complexes. Mol Biotechnol 23(1):83-86. 
21. Altschul S F, Gish W, Miller W, Myers E W, Lipman D J (1990) Basic local alignment search tool. J Mol Biol 215:403-410.

22. Muhire B, Varsani A, Martin D P (2014) SDT: A virus classification tool based on pairwise sequence alignment and identity calculation. PLoS One 9:e108277.

23. Tamura K, Stecher G, Peterson D S, Filipski A, Kumar S (2013) MEGA6: Molecular Evolutionary Genetics Analysis Version 6.0.Mol Biol Evol 30(12):2725-2729.

24. Martin D P, Murrell B, Golden M, Khoosal A, Muhire B M (2015) RDP4: Detection and analysis of recombination patterns in virus genomes.Virus Evol 1(1):vev003.

25. Briddon R W, Navas-Castillo J, Fiallo-Olivé E. (2016) ICTV taxonomic proposal 2016.021akP.A.v2.Tolecusatellitidae. Create the Tolecusatellitidae, a new family of single-stranded DNA satellites with two genera.

26. Leke W N, Kvarnheden A, Avelar S, Brown J K (2020) Molecular characterization of two previously undescribed begomovirus-associated alphasatellite molecules infecting malvaceous species in Cameroon. Arch Virol 165:775-779.

27. Wu C Z, Zhou X P (2006) First report of malvastrum leaf curl virus infecting papaya. J Plant Pathol 88(3):342.

\section{Figures}




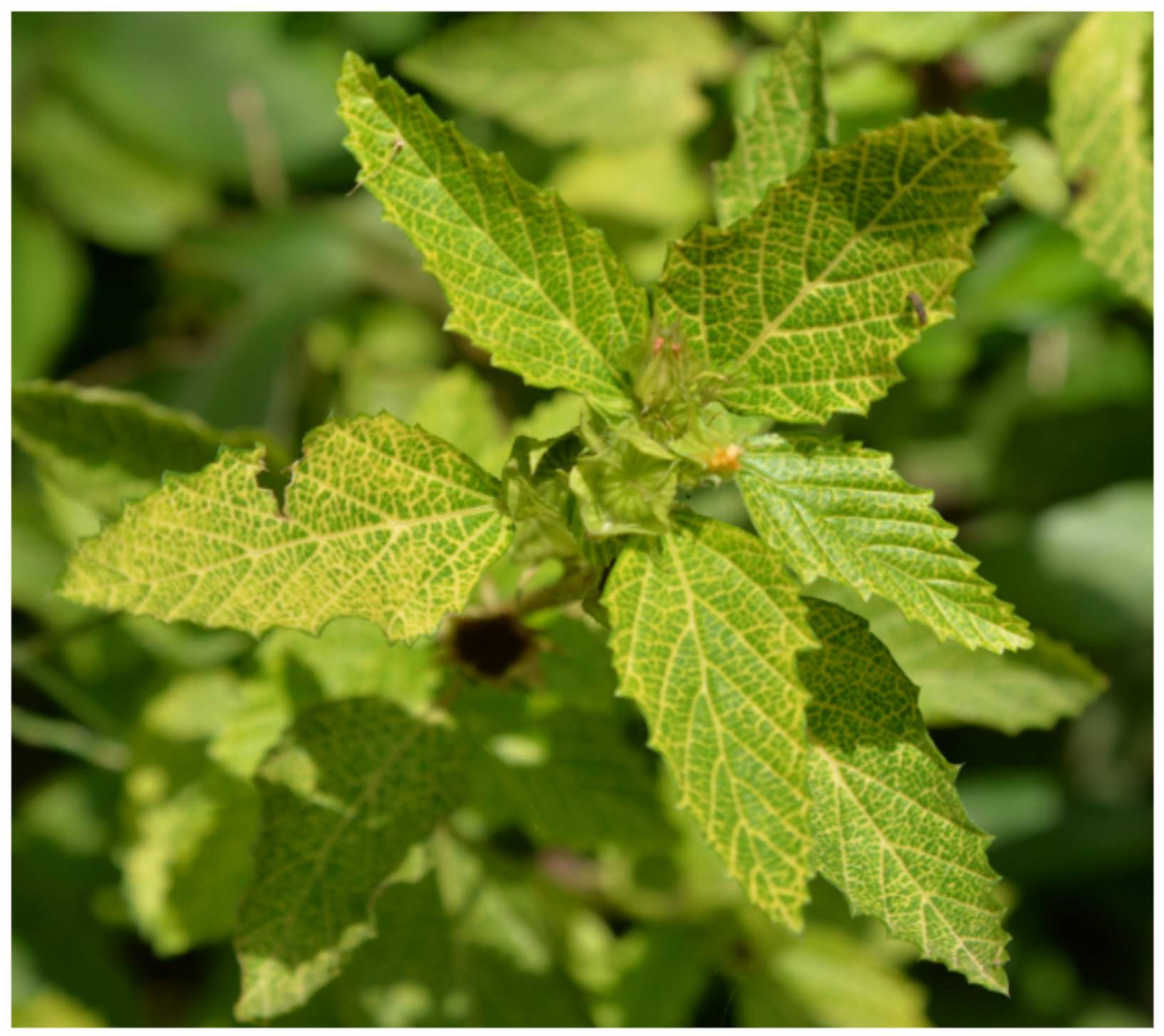

Figure 1

Malvastrum coromandelianum plant exhibiting yellow vein symptoms 


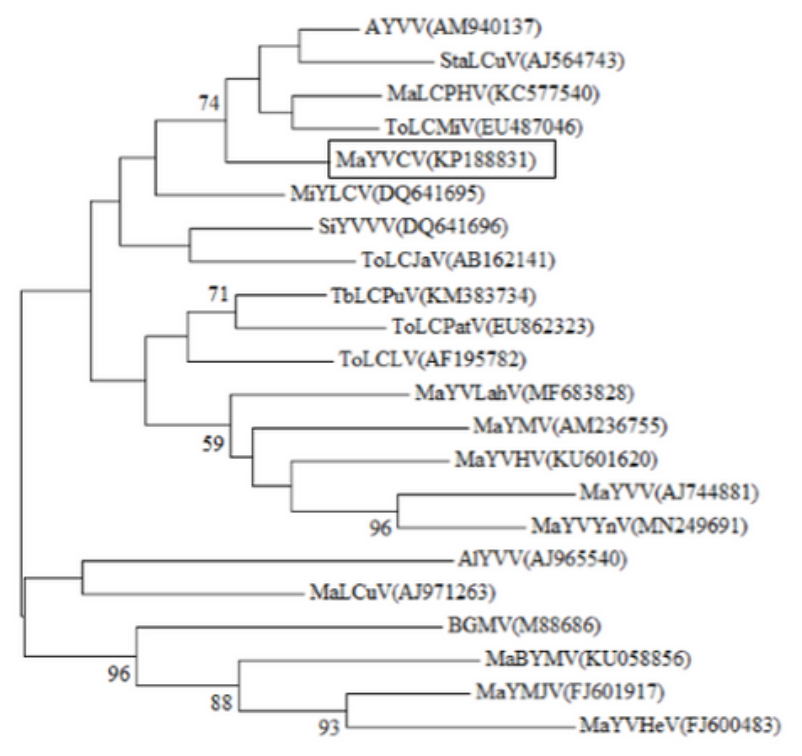

$\longmapsto$

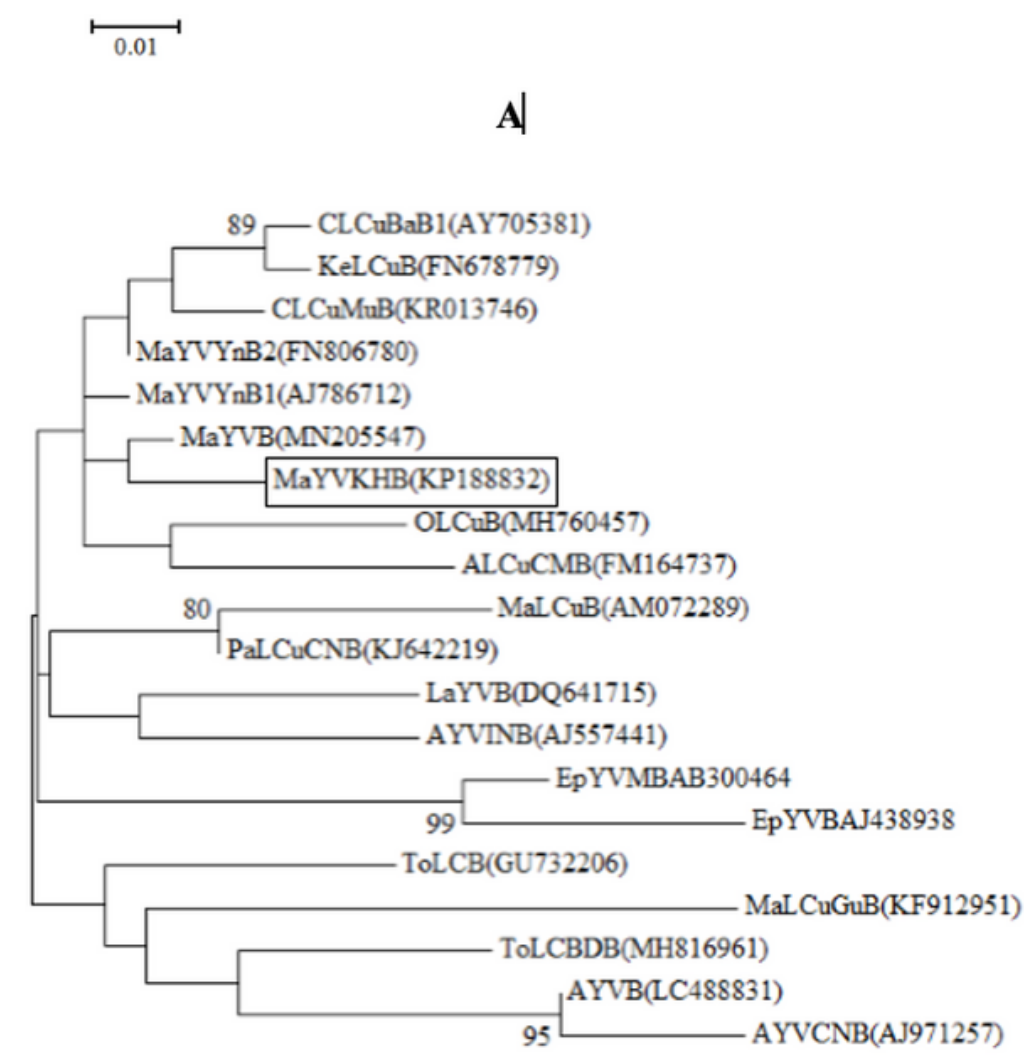

$\stackrel{\longmapsto}{0.005}$
Old World

begomoviruses

New World

begomoviruses

B

\section{Figure 2}

Phylogenetic tree showing the relationships of the complete genome sequence of MaYVCV to other begomoviral sequences (A) and of MaYVKHB to closely related betasatellites (B). The tree was constructed using the maximum-likelihood method implemented in MEGA 6.0. The bootstrap (>50\%) consensus tree was inferred from 1000 iterations. AYVV, ageratum yellow vein virus; BGMV, bean golden mosaic virus; MaBYMV, malvastrum bright yellow mosaic virus; MaLCPHV, malvastrum leaf curl 
Philippines virus; MaLCuV, malvastrum leaf curl virus; MaYMJV, malvastrum yellow mosaic Jamaica virus; MaYMV, malvastrum yellow mosaic virus; MaYVCV, malvastrum yellow vein Cambodia virus; $\mathrm{MaYVHeV}$, malvastrum yellow mosaic Helshire virus; MaYVHV, malvastrum yellow vein Honghe virus; MaYVLahV, malvastrum yellow vein Lahore virus; MaYVV, malvastrum yellow vein virus; MaYVYnV, malvastrum yellow vein Yunnan virus; MiYLCV, mimosa yellow leaf curl virus; SiYVVV, sida yellow vein Vietnam virus; StaLCuV, stachytarpheta leaf curl virus; TbLCPuV, tobacco leaf curl Pusa virus; ToLCJaV, tomato leaf curl Java virus; ToLCMiV, tomato leaf curl Mindanao virus; ToLCLV, tomato leaf curl Laos virus; ToLCPatV, tomato leaf curl Patna virus; ALCUCMB, ageratum leaf curl Cameroon betasatellite; AYVB, ageratum yellow vein betasatellite; $A Y V C N B$, ageratum yellow vein China betasatellite; AYVINB, ageratum yellow vein India betasatellite; CLCuBaB1, cotton leaf curl Bangalore betasatellite 1; CLCuMuB, cotton leaf curl Multan betasatellite; EpYVMB, eupatorium yellow vein mosaic betasatellite; EpYVB, eupatorium yellow vein betasatellite; KeLCuB, kenaf leaf curl betasatellite; LaYVB, Lindernia anagallis yellow vein betasatellite; MaLCuGuB, malvastrum leaf curl Guangdong betasatellite; MaYVB, malvastrum yellow vein betasatellite; MaYVKHB, malvastrum yellow vein Cambodia betasatellite; MaYVYnB1, malvastrum yellow vein Yunnan betasatellite 1; MaYVYnB2, malvastrum yellow vein Yunnan betasatellite 2; MaLCuB, malvastrum leaf curl betasatellite; OLCuB, okra leaf curl betasatellite; PaLCuCNB, papaya leaf curl China betasatellite; ToLCB, tomato leaf curl betasatellite; ToLCBDB, tomato leaf curl Bangladesh betasatellite 